Augusto César Leal da Silva Leonel ${ }^{1}$, Caio Belém Rodrigues Barros Soares ${ }^{1}$, Jurema Freire Lisboa de Castro ${ }^{1}$, Paulo Rogério Ferreti Bonan², Flávia Maria de Moraes Ramos-Perez ${ }^{1}$, Danyel Elias da Cruz Perez ${ }^{1}$

\title{
Knowledge and Attitudes of Primary Health Care Dentists Regarding Oral Cancer in Brazil
}

\section{Znanje i stajališta primarnih doktora dentalne medicine $o$ oralnom karcinomu u Brazilu}

\author{
${ }^{1}$ Department of Clinical and Preventive Dentistry, School of Dentistry, Universidade Federal de Pernambuco, Recife, Pernambuco, Brazil. \\ Zavod za preventivnu stomatologiju Stomatološkog fakulteta Državnog sveučilišta Department Pernambuco, Recife, Brazil \\ 2 School of Dentistry, Stomatology Unit, Universidade Federal da Paraíba, João Pessoa, Paraíba, Brazil \\ Stomatološki fakultet Državnog sveučilišta Paraíba, João Pessoa, Brazil
}

\begin{abstract}
Objective: The aim of this study was to evaluate the knowledge and attitudes of dentists working in Primary Health Care Units from a Brazilian city, regarding oral cancer. Materials and methods: A prospective, cross-sectional, epidemiologic survey was performed. Seventy-one dentists from Primary Health Care Units were contacted at their workplace, and participated of the study. Data were collected through a self-administered questionnaire of 31 multiple-choice questions addressing the main clinical features and risk factors for oral cancer. The questionnaire was divided into two sections: questions related to general data and self-perception of the participants regarding personal knowledge of oral cancer, and objective questions related to general information on oral cancer (clinical features, characteristics, traits, and risk factors). The data were tabulated and analyzed by descriptive statistics. Results: Participants were mostly females (81.5\%), less than 40 years of age (57.7\%), who underwent training $10-20$ years ago $(47.9 \%)$. Most respondents $(66.2 \%)$ considered their level of knowledge about oral cancer to be satisfactory. However, only $26.8 \%$ of tem felt that they were able to carry out diagnostic procedures for oral cancer. Most of them (95.8\%) were interested in participating in training courses on Oral Diagnostics; $56.3 \%$ of them reported not having received any training or guidance on how to conduct an examination to detect oral cancer during undergraduate training. Conclusions: These findings are consistent with previous reports and point to the need for new public policies to enable early diagnosis of oral cancer and a review of training in Oral Diagnostics in dental schools.
\end{abstract}

Received: August 21, 2018

Accepted: February 12, 2019

Address for correspondence Augusto César Leal da Silva Leonel Universidade Federal de Pernambuco Departamento de Clínica e Odontologia Preventiva.

4th Travessa Professor Artur de Sá, s/n. Cidade Universitária.CEP: 50740 521.

Recife/PE, Brazil.

Phone Number: +55-87-99955-5788.

Fax: +55-81-2126-8817

augustocleal@hotmail.com

Key words

Mouth Neoplasms; Health Knowledge, Attitudes, Practice; Dentists; Primary Health Care

\section{Introduction}

Oral cancer is a global health care problem (1). There were nearly 300,000 new cases and 145,000 deaths due to oral cancer in the world, reported in 2012 (2), making it one of the ten most common cancers (3). In Brazil, during 2018-2019, new onset oral cancer is estimated to occur in 11,200 men and 3,500 women. This corresponds to an estimated risk of 10.86 new cases per 100,000 men and 3.28 per 100,000 women (4).

The most common risk factors associated with oral cancer are tobacco and alcohol consumption (5). However, regardless of the risk factors associated with the disease, the most important factor for patient survival is the stage at which it is diagnosed (2). Most oral cancers are diagnosed when clinical signs and/or symptoms are already present. At this point, about $70 \%$ of all cases are in an advanced clinical stage (6). Lack of patient information combined with inadequately trained health professionals are usually the main reasons for
Uvod

Rak usne šupljine je globalni zdravstveni problem (1). Istaknimo da je diljem svijeta zabilježeno gotovo 300 tisuća novih slučajeva i 145 tisuća smrti zbog raka usne šupljine (2), što ga čini jednim od deset najčešćih vrsta (3). U Brazilu, tijekom 2018. i 2019. godine procjenjuje se da je od toga raka oboljelo 11200 muškaraca i 3500 žena. To odgovara procijenjenom riziku od 10,86 novih slučajeva na 100000 muškaraca i 3,28 na 100000 žena (4).

Konzumacija duhana i alkohola najčešći su rizični čimbenici povezani s oralnim karcinomom (5). No bez obzira na to, najvažniji čimbenik za preživljavanje bolesnika jest faza u kojoj se bolest dijagnosticira (2). Naime, većina oralnih karcinoma dijagnosticira se kada su se klinički znakovi i/ili simptomi već pojavili. Trenutačno je oko $70 \%$ svih slučajeva u napredovaloj kliničkoj fazi (6). Nedovoljno informiranje pacijenata, u kombinaciji s neodgovarajuće osposobljenim zdravstvenim osobljem, glavni su razlozi za kasnu dijagno- 
the late diagnosis of oral cancer (7). Late diagnosis also occurs because patients of low socioeconomic status have limited access to primary health care (8).

The known risk behaviors associated with oral carcinogenesis demonstrate that more than $80 \%$ of all oral cancers can be prevented. According to studies around the world, the preventive strategy, especially in developing countries, the goal should be primary prevention, including health education and corrective lifestyle interventions $(1-3,5-7,9)$.

A recent Spanish study revealed that the knowledge and attitudes of health care dentists can contribute significantly to changing the current scenario in oral cancer (1). An evaluation of the knowledge and attitudes about oral cancer among these professionals is of utmost importance. The information gained from such evaluation may help to assess the need to implement public policies aimed at continued education. Therefore, the aim of the present study was to evaluate the knowledge and attitudes towards oral cancer of Brazilian dentists from Primary Health Care Units.

\section{Subjects and methods}

The present study was carried out in the Primary Health Care Units (named Family Health Units), in Recife, Pernambuco, Brazil. A prospective, cross-sectional, epidemiologic survey was performed. The study was approved by the Local Research Ethics Committee (protocol l\# 29642314.6.0000.5208).

The study was performed between February and June, 2015. The sample included 71 dentists, who consented to participate and answered the questionnaire. All participants were selected by random sampling. The dentists who were confined to administrative tasks were excluded from the survey.

The registry and data collection were carried out by means of a self-administered questionnaire of 31 multiplechoice questions addressing the main clinical features and risk factors for oral cancer. The questionnaire was divided into two sections: 1) Questions related to general and demographics data of the participants (age, gender, time since graduation, attitudes towards patients with oral cancer and self-perception regarding personal knowledge of oral cancer); and 2) Objective questions related to general information on oral cancer (clinical features, characteristics, traits, and risk factors). The questionnaire also included questions related to potentially malignant disorders of the oral cavity.

The objective of the present study was explained before the study was commenced. Data confidentiality and the right to leave the study at any point of time were ensured by consenting to the terms of the study. All participants signed the informed consent form. In addition to verbal explanation and description of the study, each participant received a copy of the informed consent form along with the self-administered questionnaire.

A statistical analysis was carried out using the SPSS ver. 20.0 software (Statistical Package for the Social Sciences, Chicago, IL, USA). Descriptive statistics were obtained for variables including age, time since graduation, attitudes to- zu te bolesti (7). Kasna dijagnoza pojavljuje se i zato što bolesnici niskoga socijalno-ekonomskoga statusa imaju ograničen pristup primarnoj zdravstvenoj zaštiti (8).

Poznata rizična ponašanja povezana $s$ karcinogenezom usta pokazuju da se više od $80 \%$ svih oralnih karcinoma može spriječiti. Prema istraživanjima diljem svijeta, preventivna strategija, posebno u zemljama u razvoju, trebala bi imati kao cilj primarnu prevenciju, uključujući zdravstvenu izobrazbu i korektivne intervencije u vezi s načinom života $(1-3,5-7,9)$.

$\mathrm{U}$ nedavnom španjolskom istraživanju istaknuto je da znanje i stajališta zdravstvenog osoblja i doktora dentalne medicine mogu znatno pridonijeti promjeni trenutačnog stanja povezanog $s$ tom bolešću (1). Procjena znanja i stajališta o oralnom raku među tim stručnjacima iznimno je važna. Informacije dobivene takvom procjenom mogu pomoći u procjeni je li potrebna provedba novih javnih zdravstvenih smjernica sa svrhom nastavka obrazovanja. Zato je cilj ovog istraživanja bio procijeniti znanje i stajališta o oralnom raku brazilskih stomatologa u jedinicama primarne zdravstvene zaštite.

\section{Ispitanici i metode}

Ovo prospektivno, presječno, epidemiološko istraživanje obavljeno je u jedinicama primarne zdravstvene zaštite (pod nazivom Obiteljske zdravstvene jedinice) u Recifeu (Pernambuco, Brazil). Odobrio ga je Odbor za etička istraživanja na lokalnoj razini (protokol br. 29642314.6.0000.5208).

Istraživanje je trajalo od veljače do lipnja 2015. godine. Uzorak je obuhvatio 71 doktora dentalne medicine. Svi su pristali sudjelovati te su odgovorili na pitanja u upitniku. Odabrani su slučajnim uzorkovanjem. Doktori dentalne medicine ograničeni na administrativne poslove, bili su isključeni iz istraživanja.

Registar i prikupljanje podataka provedeno je na temelju upitnika u kojemu je bilo 31 pitanje s višestrukim izborom o glavnim kliničkim značajkama i rizičnim čimbenicima kad je riječ o raku usne šupljine. Upitnik je bio podijeljen na dva dijela - na pitanja o općim i demografskim podatcima sudionika (dob, spol, koliko je godina proteklo od završetka studija, stajališta o pacijentima s oralnim karcinomom i samopercepcija o osobnom znanju o oralnom raku) te na objektivna pitanja koja se odnose na opće informacije o oralnom raku (klinička obilježja, karakteristike, svojstva i rizični čimbenici). Upitnik je sadržavao i pitanja o potencijalno malignim poremećajima u usnoj šupljini.

Cilj ovog istraživanja objašnjen je prije njegove provedbe. Povjerljivost podataka i pravo na odustajanje od sudjelovanja u bilo kojem trenutku, osiguravali su pristanak na uvjete studije. Svi sudionici potpisali su informirani pristanak. Uz verbalno objašnjenje i opis studije, svaki sudionik dobio je i kopiju obrasca za informirani pristanak zajedno s upitnikom koji su sami popunili.

Statistička analiza obavljena je softverom SPSS ver. 20.0 (statistički paket za društvene znanosti, Čikago, IL, SAD). Deskriptivna statistika dobivena je za varijable dob, godine protekle od diplomiranja, stajališta o pacijentima s oralnim karcinomom i samopercepcija o osobnom znanju o toj 
wards patients with oral cancer, and self-perception regarding personal knowledge of oral cancer (clinical characteristics, traits, and risk factors). The variables of "time since graduation" and "self-perception regarding personal knowledge about oral cancer" were compared to other variables using the chi-square test $(\mathrm{p} \leq 0.05)$.

\section{Results}

\section{General characteristics of the studied population}

The study sample comprised 71 dentists, 58 females $(81.7 \%)$ and 13 males (18.3\%). Most of them were 40 years old or less $(31-57.7 \%)$. Thirty-four $(47.9 \%)$ participants had graduated 10-20 years ago, 28 (39.4\%) had graduated more than 20 years ago, and $9(12.7 \%)$ had graduated less than 2 years ago. There were only 3 smokers (4.2\%) among the participants.

\section{Clinical features of oral cancer}

Regarding the clinical findings related to oral cancer, 47 (66.2\%) participants indicated that squamous cell carcinoma was the most common type of oral cancer. Fifty-one (71.9\%) contributors indicated that the tongue and the floor of the mouth were the most frequent sites of oral cancer, while 7 $(9.8 \%)$ did not respond to this question. Sixty-six dentists $(93 \%)$ indicated that oral cancer most commonly affects patients over 40 years old, and 54 (76.1\%) also indicated that oral cancer is more frequently diagnosed at an advanced clinical stage (Table 1). bolesti (kliničke karakteristike, svojstva i rizični čimbenici). Varijable godine protekle od diplomiranja i samopercepcija o osobnom znanju o oralnom raku uspoređene su s ostalim varijablama korištenjem hi-kvadrat testa $(\mathrm{p} \leq 0,05)$.

\section{Rezultati}

\section{Opće karakteristike ispitivane populacije}

Uzorak je obuhvatio 71 doktora dentalne medicine - 58 žena $(81,7 \%)$ i 13 muškaraca (18,3 \%). Najviše ih je bilo u dobi od 40 godina ili manje $(31-57,7 \%)$. Njih $34(47,9 \%)$ diplomiralo je prije 10 do 20 godina, 28 (39,4\%) prije više od 20 godina, a $9(12,7 \%)$ prije manje od dvije godine. Među sudionicima bila su samo tri pušača $(4,2 \%)$.

\section{Kliničke značajke raka usne šupljine}

Kad je riječ o kliničkim nalazima o raku usne šupljine, 47 (66,2 \%) sudionika izjavilo je da je karcinom pločastih stanica najčešći oblik oralnoga raka. Da su jezik i dno usne šupljine najčešća mjesta na kojima se pojavljuje ta bolest, naveo je 51 sudionik $(71,9 \%)$, a $7(9,8 \%)$ nije odgovorilo na to pitanje. Dodajmo da je 66 doktora dentalne medicine (93\%) zaokružilo odgovor da oralni karcinom najčešće pogađa pacijente starije od 40 godina, a 54 (76,1 \%) naznačilo je da se rak oralne šupljine najčešće dijagnosticira u kasnoj kliničkoj fazi (tablica 1.).

Table 1 Distribution of the answers regarding clinical features of oral cancer

Tablica 1. Raspodjela odgovora o kliničkim obilježjima oralnog raka

Variables • Varijable

What is the most common type of oral cancer? •

Koji je najčešći oblik raka usne šupljine?

\begin{tabular}{|c|c|c|}
\hline \multirow{6}{*}{$\begin{array}{l}\text { What is the most common type of oral cancer? } \\
\text { Koji je najčešći oblik raka usne šupljine? }\end{array}$} & Squamous Cell Carcinoma $\bullet$ Karcinom pločastih stanica & $47(66.2)$ \\
\hline & Mucoepidermoid carcinoma $\bullet$ Mukoepidermoidni karcinom & $3(4.2)$ \\
\hline & Ameloblastoma $\bullet$ Ameloblastom & $3(4.2)$ \\
\hline & Kaposi Sarcoma • Kapošijev sarkom & $2(2.8)$ \\
\hline & Lymphoma $\bullet$ Limfom & $1(1.4)$ \\
\hline & Do not know $\bullet$ Ne znam & $15(21.1)$ \\
\hline \multirow{5}{*}{$\begin{array}{l}\text { What is the most common site affected by the oral } \\
\text { cancer? } \bullet \text { Koja je najčeśća lokalizacija raka usne } \\
\text { šupljine? }\end{array}$} & Tongue/Floor of mouth $\bullet$ Jezik/dno usne šupljine & $51(71.9)$ \\
\hline & Buccal mucosa $\bullet$ Obrazna sluznica & $8(11.2)$ \\
\hline & Palate $\bullet$ Nepce & $3(4.2)$ \\
\hline & Gum• Desni & $2(2.8)$ \\
\hline & Do not know $\bullet$ Ne znam & $7(9.8)$ \\
\hline \multirow{4}{*}{$\begin{array}{l}\text { What is the most age group affected by the oral } \\
\text { cancer? } \bullet \text { Koja je dobna skupina najčešćc zahvaćena } \\
\text { rakom usne šupljine? }\end{array}$} & Under 18 years $\bullet$ Mlađa od 18 godina & $0(0.0)$ \\
\hline & Between 18 and 40 year $\bullet$ Između 18 i 40 godina & $2(2.8)$ \\
\hline & Above 40 years $\bullet$ Starija od 40 godina & $66(93.0)$ \\
\hline & Do not know $\bullet$ Ne znam & $3(4.2)$ \\
\hline \multirow{3}{*}{$\begin{array}{l}\text { What is the most frequent clinical stage in which } \\
\text { the oral cancer is diagnosed? • Koja je najčeśća } \\
\text { klinička faza u kojoj se dijagnosticira rak usne } \\
\text { šupljine? }\end{array}$} & Initial $\bullet$ Početna & $7(9.9)$ \\
\hline & Advanced $\bullet$ Uznapredovala & $54(76.1)$ \\
\hline & Do not know $\bullet$ Ne znam & $10(14.0)$ \\
\hline \multirow{6}{*}{$\begin{array}{l}\text { Which of the following diseases are commonly } \\
\text { related with the development of oral cancer? } \bullet \text { Koje } \\
\text { su od sljedećih bolesti obično povezane } s \text { razvojem } \\
\text { raka usne šupljine? }\end{array}$} & Leukoplakia • Leukoplakija & $61(85.9)$ \\
\hline & Candidiasis $\bullet$ Kandidijaza & $4(5.6)$ \\
\hline & Stomatitis & $3(4.2)$ \\
\hline & Pemphigus vulgaris & $1(1.4)$ \\
\hline & Geographic tongue $\bullet$ Geografski jezik & $0(0.0)$ \\
\hline & Do not know $\bullet$ Ne znam & $2(2.8)$ \\
\hline
\end{tabular}




\section{Risk factors associated with oral cancer}

Most participants indicated that tobacco (71, 100\%), alcohol (70,98.6\%) consumption, exposure to sunlight (69, $97.2 \%)$, and family history $(68,95.8 \%)$ were risk factors for oral cancer. Emotional stress, and low intake of fruits and vegetables were indicated as risk factors by $56(78 \%)$ and 42 (59.2\%) participants, respectively. Ill-fitting prostheses (63, $88.7 \%)$, deficient oral hygiene $(56,78.9 \%)$, and the presence of tooth decay $(56,78.9 \%)$ were also identified as risk factors for oral cancer. Oral sex and parenteral drug abuse were identified as risk factors for oral cancer by $36(50.7 \%)$ and 15 (21.1\%) dentists, respectively (Table 2 ).

\section{Rizični čimbenici povezani s oralnim karcinomom}

Većina sudionika navela je da su duhan $(71-100 \%)$, alkohol (70 - 98,6 \%), izloženost sunčevu svjetlu (69-97,2 $\%)$ i obiteljska anamneza (68 - 95,8 \%) rizični čimbenici za rak usne šupljine. Emocionalni stres i nizak unos voća i povrća istaknulo je kao rizične čimbenike 56 (78\%), odnosno 42 $(59,2 \%)$ sudionika. Loše proteze $(63-88,7 \%)$, nedovoljna higijena usne šupljine $(56-78,9 \%)$ i karijes $(56-79,9 \%)$ također su označeni kao rizični čimbenici. Oralni seks i parenteralnu zlouporabu droga istaknulo je 36 (50,7 \%), odnosno $15(21,1 \%)$ doktora dentalne medicine (tablica 2.).

\begin{tabular}{|c|c|c|}
\hline Variables $\bullet$ Varijable & & n $(\%)$ \\
\hline \multirow{2}{*}{ Parenteral drug abuse $\cdot$ Parenteralna primjena droga } & Yes $\bullet \mathrm{Da}$ & $15(21.1)$ \\
\hline & $\mathrm{No} \bullet \mathrm{Ne}$ & $56(78.9)$ \\
\hline \multirow{2}{*}{ Alcohol consumption $\bullet$ Konzumacija alkohola } & Yes $\bullet \mathrm{Da}$ & $70(98.6)$ \\
\hline & $\mathrm{No} \bullet \mathrm{Ne}$ & $1(1.4)$ \\
\hline \multirow{2}{*}{ Tobacco consumption $\bullet$ Konzumacija duhanskih proizvoda } & Yes $\bullet \mathrm{Da}$ & $71(100.0)$ \\
\hline & $\mathrm{No} \bullet \mathrm{Ne}$ & $0(0.0)$ \\
\hline \multirow{2}{*}{ Family history of cancer $\bullet$ Obiteljska anamneza raka } & Yes $\bullet \mathrm{Da}$ & $68(95.8)$ \\
\hline & $\mathrm{No} \cdot \mathrm{Ne}$ & $3(4.2)$ \\
\hline \multirow{2}{*}{ Emotional stress $\bullet$ Emocionalni stres } & Yes $\bullet \mathrm{Da}$ & $56(78.9)$ \\
\hline & $\mathrm{No} \bullet \mathrm{Ne}$ & $15(21.1)$ \\
\hline \multirow{2}{*}{ Low vegetables and fruits intake $\bullet$ Nizak unos voća i povrća } & Yes $\bullet \mathrm{Da}$ & $42(59.2)$ \\
\hline & $\mathrm{No} \bullet \mathrm{Ne}$ & $29(40.8)$ \\
\hline \multirow{2}{*}{ Oral sex $\bullet$ Oralni seks } & Yes $\bullet \mathrm{Da}$ & $36(50.7)$ \\
\hline & $\mathrm{No} \bullet \mathrm{Ne}$ & $35(49.3)$ \\
\hline \multirow{2}{*}{ Ill-fitting prostheses $\bullet$ Loše zubne proteze } & Yes $\bullet \mathrm{Da}$ & $63(88.7)$ \\
\hline & $\mathrm{No} \bullet \mathrm{Ne}$ & $8(11.3)$ \\
\hline \multirow{2}{*}{ Deficient oral hygiene $\bullet$ Loša oralna higijena } & Yes $\bullet \mathrm{Da}$ & $56(78.9)$ \\
\hline & $\mathrm{No} \bullet \mathrm{Ne}$ & $15(21.1)$ \\
\hline \multirow{2}{*}{ Presence of decay teeth $\bullet$ Zubi $s$ karijesom } & Yes $\bullet \mathrm{Da}$ & $53(74.6)$ \\
\hline & $\mathrm{No} \bullet \mathrm{Ne}$ & $18(25.4)$ \\
\hline \multirow{2}{*}{ Solar exposure $\bullet$ Izloženost suncu } & Yes $\bullet \mathrm{Da}$ & $69(97.2)$ \\
\hline & $\mathrm{No} \bullet \mathrm{Ne}$ & $2(2.8)$ \\
\hline \multirow{2}{*}{ Hot food and drink $\bullet$ Vruća hrana i piće } & Yes $\bullet \mathrm{Da}$ & $33(46.5)$ \\
\hline & $\mathrm{No} \bullet \mathrm{Ne}$ & $38(53.5)$ \\
\hline
\end{tabular}

\section{Clinical practice related to the oral cancer}

When asked about performing physical examination to identify the presence of oral lesions, 70 (98.6\%) of them confirmed this practice at the first appointment. Regarding further course of action when an oral lesion was identified, 67 (94.4\%) participants stated that they would refer the patient to a specialist in Oral Diagnosis, two $(2.8 \%)$ would refer to a specialized hospital, and two (2.8\%) would confirm the diagnosis themselves.

\section{Knowledge of oral cancer, interest, and perception}

On analysis of the general features of oral cancer, 47 (66.2\%) participants considered their knowledge to be adequate. Nineteen (26.8\%) dentists stated that they were confident to carry out diagnostic procedures related to oral cancer. Most study participants $(60-84.5 \%)$ pointed out that their

\section{Klinička praksa povezana s oralnim karcinomom}

Na pitanje obavljaju li fizikalni pregled kako bi ustanovili postoje li oralne lezije, njih $70(98,6 \%)$ potvrdno je odgovorilo već na prvom sastanku. Kad je riječ o daljnjim postupcima nakon što je identificirana oralna lezija, $67(94,4 \%)$ sudionika izjavilo je da bi uputili pacijenta specijalistu za oralnu dijagnozu, dva $(2,8 \%)$ bi ga poslala u specijaliziranu bolnicu, a dva $(2,8 \%)$ bi sami potvrdili dijagnozu.

\section{Poznavanje raka usne šupljine, interes i percepcija}

Kad je riječ o analizi općih svojstava oralnog karcinoma, $47(66,2 \%)$ sudionika smatralo je da je njihovo znanje adekvatno. Njih 19 (26,8 \%) izjavilo je da su sposobni obaviti dijagnostičke postupke vezane za rak usne šupljine. Većina je $(60-84,5 \%)$ istaknula da njihovi pacijenti nisu bili dobro 
patients were not well informed about preventive procedures and general features of oral cancer.

Forty $(56.3 \%)$ participants stated that they never received any information related to the diagnosis of oral cancer during undergraduate training. Thirty-six $(50.7 \%)$ participants had not enrolled in any continued education course during the previous two years. However, the majority $(68,95.8 \%)$ expressed interest in undergoing continued education courses in the future. Moreover, 70 (98.6\%) participants acknowledged the importance of dentists in the prevention and early diagnosis of oral cancer.

Statistical analysis did not show any significant association between the time since graduation and self-perception regarding personal knowledge about oral cancer and the other variables $(\mathrm{p}=0.2)$.

\section{Discussion}

The incidence of and death rate due to oral cancer can be minimized if adequate measures are undertaken to enable prevention, early diagnosis, and expeditious treatment (10). In general, dentists are expected to have adequate knowledge on the risk factors and clinical features of oral cancer, regardless of its implementation in public health or private practice. However, there are some indications, such as the persistence of oral cancer as a major health problem, that this assumption may not have been fulfilled in routine primary care dentistry or in private practices.

Most of the participants were 40 years old or younger. Therefore, it is a young population having a long professional career ahead, which requires further education, to enable prevention and early diagnosis of oral cancer. With respect to professional experience, $47.9 \%$ of participants were between 10 and 20 years, $39.4 \%$ were more than 20 years, and $12.7 \%$ were up to 2 years since graduation. Based on the above information regarding professional experience, it would appear that a significant number of participants would be confident of carrying out clinical procedures to diagnose oral cancer. However, only $26 \%$ of dentists expressed such confidence. The absence of association between duration since graduation and the other variables studied shows that some participants assumed to have a good knowledge of oral cancer even though their responses to the questionnaire did not support this claim.

In the present study, $66.2 \%$ of the participants pointed out that squamous cell carcinoma was the most common type of oral cancer, while $33.8 \%$ did not know or answered incorrectly. Another study revealed that $18.4 \%$ of surveyed dentists were unaware of the most common type of oral cancer (11). This is of concern, because it shows a lack of knowledge of the biological behavior of the tumor, apart from likelihood of compromising the initial oral examination of patients.

The primary health care dentists correctly pointed out that the tongue and the floor of the mouth were the most common sites for oral cancer, with most tumors affecting patients above 40 years old, which is similar to the findings from other studies (12). Among the potentially malignant disorders, leukoplakia is the most prevalent, with a $5 \% \mathrm{ma}-$ informirani o preventivnim postupcima i općim značajkama oralnoga karcinoma.

Da nikada nisu dobili nikakve informacije vezane za dijagnozu oralnoga karcinoma tijekom dodiplomskog obrazovanja, navelo je 40 ispitanika (56,3\%). Njih $36(50,7 \%)$ nije sudjelovalo ni u kojem obliku nastavka izobrazbe tijekom protekle dvije godine. No većina $(68-95,8 \%)$ je istaknula da je zainteresirana za daljnju edukaciju. Štoviše, 70 (98,6 \%) sudionika izjavilo je da je doktor dentalne medicine iznimno važan u prevenciji i ranoj dijagnostici oralnoga karcinoma.

Statistička analiza nije pokazala značajnu povezanost između godina proteklih od završetka studija i samopercepcije o osobnom znanju o oralnom raku i drugim varijablama $(\mathrm{p}=0,2)$.

\section{Rasprava}

Učestalost i smrtnost zbog raka usne šupljine mogu se znatno smanjiti ako se poduzmu odgovarajuće mjere kako bi se omogućila prevencija, rana dijagnoza i brzo liječenje (10). Od doktora dentalne medicine općenito se očekuje odgovarajuće znanje o rizičnim čimbenicima i kliničkim značajkama oralnoga karcinoma, bez obzira na primjenu u javnom zdravstvu ili privatnoj praksi. No postoje neke naznake, poput postojanosti raka usne šupljine kao velikoga zdravstvenog problema, da ta pretpostavka možda nije ispunjena u rutinskoj stomatologiji primarne zaštite ili u privatnoj praksi.

Većina sudionika bila je u dobi od 40 godina ili mlađa. Dakle, upravo je pred tom mladom populacijom duga profesionalna karijera koja zahtijeva daljnju izobrazbu kako bi se omogućila prevencija i rano otkrivanje raka usne šupljine. Kad je riječ o profesionalnom iskustvu, u 47,9\% slučajeva ono bilo je između 10 i 20 godina, u 39,4 \% slučajeva bilo je iznad 20 godina, a 12,7 \% do dvije godine. Na temelju tih podataka o profesionalnom iskustvu čini se da bi znatan broj sudionika bio siguran u obavljanju kliničkih postupaka za dijagnosticiranje oralnog karcinoma. No samo je $26 \%$ doktora dentalne medicine izrazilo takvo stajalište. To što nema povezanosti između godina proteklih od završetka studija i drugih ispitivanih varijabli, pokazuje da neki sudionici pretpostavljaju da dobro poznaju oralni karcinom, iako njihovi odgovori u upitniku ne podupiru tu tvrdnju.

$\mathrm{U}$ ovom istraživanju je $66,2 \%$ ispitanika odgovorilo da je karcinom pločastih stanica najčešći oblik oralnoga karcinoma, a 33,8 \% nije znalo ili je odgovorilo netočno. U jednom drugom istraživanju $18,4 \%$ ispitanih doktora dentalne medicine nije znalo za najčešći oblik oralnoga karcinoma (11). To zabrinjava jer pokazuje nedostatak znanja o biološkom ponašanju tumora, a to može ugroziti početni oralni pregled pacijenata.

Doktori dentalne medicine primarne zdravstvene zaštite ispravno su istaknuli da su jezik i dno usne šupljine najčešća mjesta za pojavu raka usne šupljine, pri čemu je većina tumora uočena kod bolesnika starijih od 40 godina, što je slično nalazima u drugim istraživanjima (12). Među potencijalno malignim poremećajima najčesća je leukoplakija, sa stopom maligne transformacije od $5 \%$ (13). Zadaća doktora dental- 
lignant transformation rate (13). The role of the dentist is of utmost importance in the diagnosis and education of the patient with leukoplakia. The present study showed that $85.9 \%$ of the participants identified leukoplakia as the condition most commonly associated with oral cancer, as observed in another survey (12).

The first preventive measure against oral cancer relies on the awareness of patients and dentists about the risk factors associated with the disease (2). Alcohol and tobacco consumption are the most important risk factors related to oral cancer, with an incremental risk when both are used concomitantly (14-16). The proportion of smokers (80\%) among patients with oral cancer is two to three times higher than in the general population, with increasing risk depending on the number of cigarettes smoked per day and the duration of smoking. Similarly, one third of men with oral cancer have a history of heavy alcohol consumption (14). Similar to previous studies $(11,13,15)$, alcohol $(98.6 \%)$, smoking (100\%) and exposure to sunlight $(97.2 \%)$ were the most frequent risk factors stated by the participants. In the current survey, low intake of fruits and vegetables was pointed out as a risk factor for oral cancer by $59.2 \%$ of participants. Epidemiological studies have shown a two-fold increase in the risk of oral cancer with low intake of fruits and vegetables (17). Moreover, Toporcov et al. (18) showed that consumption of fruit and vegetables can mitigate the harmful effects of smoking. Thus, education in dietary habits may also be an important factor in the prevention of oral cancer.

Deficient oral hygiene (78.9\%) and tooth decay $(74.6 \%)$ were pointed out as risk factors for oral cancer by a large number of participants. Even though other studies have revealed similar results (19-21), it is difficult to establish a cause and effect relationship between these factors and the development of oral cancer. There is no agreement in the literature whether deficient oral hygiene and the presence of tooth decay may expose the patient to a higher risk of developing oral cancer. Similar reasoning can be applied to ill-fitting prostheses, identified as a risk factor for oral cancer by $88.7 \%$ of participants in the present study. Some authors suggest that microorganisms present in the oral cavity produce carcinogenic acetaldehydes that potentiate the effects of alcohol and tobacco $(22,23)$. Moreover, most of the Brazilian populations do not have access to adequate dental treatment; hence, poor general oral hygiene is usually observed (24).

The Human Papilloma Virus (HPV) causes approximately $5.2 \%$ of cancers in humans, including rectal, genital, oropharyngeal, and cervical cancer. While epidemiology and correlation between HPV infection and oropharyngeal cancer is well established, many factors remain unknown regarding the association between HPV oral infection and oral cancer. Despite the limited knowledge of the epidemiology, natural history and prevention of HPV oral infection, studies show that the infection is sexually transmitted and is related to the development of some cases of oral cancer (25). It is established that approximately $5 \%$ of cases of oral cancer are related to HPV infection $(26,27)$. Although the incidence of HPV-induced oral cancer is low, dentists can guide patients on the risks of unprotected oral sex. On the other hand, the ne medicine neobično je važna u dijagnostici i edukaciji bolesnika s leukoplakijom. U ovom istraživanju uočeno je da 85,9 $\%$ ispitanika identificira leukoplakiju kao stanje koje se najčešce povezuje s oralnim karcinomom, što je zapaženo i u drugom istraživanju (12).

Prva preventivna mjera u vezi s rakom usne šupljine oslanja se na svijest pacijenata i doktora dentalne medicine kad je riječ o rizičnim čimbenicima povezanima s tom bolešću (2). Konzumacija alkohola i duhana najvažniji su rizični čimbenici povezani $s$ rakom usne šupljine, a opasnost se povećava ako se oboje koristi istodobno $(14-16)$. Udio pušača $(80$ $\%)$ među bolesnicima s oralnim karcinomom je od dva do tri puta veći negoli u općoj populaciji, a rizik se povećava ovisno o broju popušenih cigareta na dan i trajanju pušenja. Slično tomu, trećina muškaraca s oralnim karcinomom ima povijest teške konzumacije alkohola (14). Slično dosadašnjim istraživanjima $(11,13,15)$, alkohol $(98,6 \%)$, pušenje $(100 \%)$ i izloženost sunčevoj svjetlosti $(97,2 \%)$ bili su najčešći rizični čimbenici koje su naveli sudionici. U sadašnjem istraživanju, $59,2 \%$ ispitanika upozorilo je na nizak unos voća i povrća kao na rizični čimbenik za oralni rak. U epidemiološkim studijama istaknuto je dvostruko povećanje rizika od raka usne šupljine ako se ne jede dovoljno voća i povrća (17). Štoviše, Toporcov i suradnici (18) dokazali su da konzumacija voća i povrća može ublažiti štetne učinke pušenja. Zato izobrazba o prehrani također može biti važan čimbenik u prevenciji raka usne šupljine.

Neodgovarajuću higijenu usne šupljine $(78,9 \%)$ i zubni karijes $(74,6 \%)$ navela je kao rizični čimbenik većina sudionika. Iako su u drugim istraživanjima dobiveni slični rezultati $(19-21)$, teško je utvrditi uzročno-posljedičnu vezu između tih čimbenika i razvoja oralnog karcinoma. U literaturi nema suglasja mogu li neodgovarajuća oralna higijena i karijes izvrgnuti pacijenta većem riziku od nastanka te bolesti. Slično razmišljanje može se primijeniti i na loše izrađene proteze koje je 88,7 \% sudionika u ovoj studiji navelo kao rizični čimbenik. Neki autori sugeriraju da mikroorganizmi u usnoj šupljini proizvode kancerogene acetaldehide koji pojačavaju djelovanje alkohola i duhana $(22,23)$. Istaknimo da većina brazilske populacije nema pristup odgovarajućem stomatološkom liječenju i zato se općenito uočava loša opća oralna higijena (24).

Humani papiloma virus (HPV) uzrokuje oko 5,2 \% karcinoma kod ljudi, uključujući rektalni, genitalni i orofaringealni rak te rak grlića maternice. Dok je epidemiologija i korelacija između infekcije HPV-om i raka ždrijela dobro poznata, mnogi čimbenici ostaju nepoznati kad je riječ o povezanosti između oralne infekcije HPV-om i oralnoga karcinoma. Unatoč ograničenom znanju o epidemiologiji, prirodnoj povijesti i prevenciji HPV-a, studije pokazuju da se infekcija prenosi spolno i da je povezana $s$ pojavom nekih slučajeva raka usne šupljine (25). Utvrđeno je da je oko $5 \%$ slučajeva oralnoga karcinoma povezano s infekcijom HPVom $(26,27)$. Iako je učestalost oralnih karcinoma induciranih HPV-om niska, doktori dentalne medicine mogu obavijestiti pacijente o opasnostima od nezaštićenoga oralnog seksa. $S$ druge strane, ispitana populacija bila je pod pogrešnim dojmom da je emocionalni stres rizičan za rak usne šu- 
populations surveyed were under the mistaken impression that emotional stress is a risk factor for oral cancer, a finding similar to that observed in another survey (10).

Most oral cancers are diagnosed at an advanced clinical stage (6). In the current study, $76.1 \%$ of the participants were aware of this fact, which is similar to the findings observed in another survey (10). Diagnostic delay may be attributed to factors associated with the patient (patient delay) or practitioners (professional delay). Although it is variable, patient delay has been reported to be approximately six months. It is estimated that patient delay of more than 3 months significantly worsens the prognosis (28). The two main components of national cancer control programs are information for the public and professionals. However, in the present study, $84.5 \%$ of the participants stated that patients are not well informed on the preventive and diagnostic aspects of oral cancer. Other factors related to the diagnostic delay of oral cancer were the limited access to primary health care for patients of low socioeconomic status, and irregular dental follow-up (8). The diagnostic delay is also related to the lack of knowledge of dentists regarding identification of oral lesions. The professional delay varies between one and five months. Oral examinations are limited to teeth and gums, and lack of knowledge of oral mucosal lesions, may be factors associated with delay in diagnosis of oral cancer (28). In the current survey, $66.2 \%$ of the dentists indicated a satisfactory knowledge regarding this; however, only $26.8 \%$ of them stated that they were confident enough to carry out diagnostic procedures related to oral cancer, as reported in other studies $(3,11)$. It is important to point out that dentists should undertake the responsibility of their role in the prevention and diagnosis of oral cancer. The majority of dentists $(98.6 \%)$ reported that their participation is essential in these processes.

During undergraduate training, $56.3 \%$ of dentists stated that they did not receive any information on how to perform a clinical examination to screen for oral cancer. These data are alarming, which suggests that during undergraduate training, adequate emphasis should be put on identifying oral lesions, especially oral cancer. The dentist should make a difference by combining theoretical knowledge with clinical skills to facilitate the early diagnosis of oral cancer. Hence, undergraduate training in dentistry and continued education courses should focus on the identification and prevention of oral cancer and other potentially malignant disorders. These measures are of utmost importance in decreasing morbidity and mortality due to oral cancer (29). Currently, the need for continued education is a prerequisite for professional performance, since new information and technological advances make the knowledge acquired during undergraduate training outdated within a short period of time (30). There is a need for regular education programs meant for updating the knowledge level of professionals $(29,30)$. However, $50.7 \%$ of participants stated that they did not subscribe to a continued education course for more than two years. On the other hand, most of them (95.8\%) showed a keen interest in such courses in the future, as was previously mentioned (2). pljine, što je nalaz sličan onome koji je uočen u drugom istraživanju (10).

Većina oralnih karcinoma dijagnosticira se u već napredovaloj kliničkoj fazi (6). U trenutačnom istraživanju, 76,1 \% sudionika bilo je svjesno te činjenice, a slično je zabilježeno i u drugom istraživanju (10). Dijagnostičko kašnjenje može se pripisati čimbenicima povezanima s pacijentom (kašnjenje pacijenta) ili praktičarima (profesionalno kašnjenje). Iako je varijabilno, zabilježeno je da pacijenti obično kasne približno šest mjeseci. Procjenjuje se da kašnjenje bolesnika dulje od tri mjeseca znatno pogoršava prognozu (28). Dvije glavne sastavnice nacionalnih programa za kontrolu raka su informacije za javnost i profesionalce. No u ovom istraživanju je 84,5 $\%$ ispitanika izjavilo da pacijenti nisu dobro obaviješteni o preventivnim i dijagnostičkim aspektima raka usne šupljine. Ostali čimbenici povezani $s$ kašnjenjem dijagnoze raka usne šuplijine bili su ograničen pristup primarnoj zdravstvenoj skrbi za pacijente s niskim socijalno-ekonomskim statusom i neredovito praćenje stanja zubala (8). Dijagnostičko kašnjenje povezano je i s nedostatkom znanja doktora dentalne medicine o identifikaciji oralnih lezija. Profesionalna kašnjenja variraju od jednoga do pet mjeseci. Oralni pregled ograničen samo na zube i desni, osim nedostatka znanja o lezijama oralne sluznice, može biti čimbenik povezan s odgodom dijagnoze oralnoga karcinoma (28). U ovom istraživanju $66,2 \%$ doktora dentalne medicine pokazalo je zadovoljavajuće znanje o tome, no samo je 26,8 \% izjavilo kako su dovoljno sigurni da mogu obaviti dijagnostičke postupke povezane s rakom usne šuplijne, a to je istaknuto i u drugim istraživanjima $(3,11)$. Važno je dodati da bi doktori dentalne medicine trebali preuzeti odgovornost za svoju zadaću u prevenciji i dijagnozi oralnog karcinoma. Većina njih $(98,6 \%)$ izjavila je da je u tim procesima njihovo sudjelovanje ključno.

Prema riječima 56,3 \% doktora dentalne medicine, tijekom dodiplomskog studiranja nisu dobili nikakve smjernice o tome kako obaviti klinički pregled za otkrivanje raka usne šupljine. Ti podatci zabrinjavaju i sugeriraju da bi se tijekom studija trebalo staviti težište na otkrivanje i određivanje oralnih lezija, posebno raka usne šupljine. Doktor dentalne medicine trebao bi pritom kombinirati teorijsko znanje i kliničku vještinu kako bi se olakšala rana dijagnoza raka usne šuplijine. Zato bi se dodiplomski studij dentalne medicine i tečajevi kontinuirane izobrazbe trebali usredotočiti na identifikaciju i prevenciju raka usne šupljine i drugih potencijalno malignih poremećaja. Te su mjere najvažnije za smanjenje morbiditeta i smrtnosti zbog te bolesti (29). Trenutačno je potreba za kontinuiranom izobrazbom preduvjet za profesionalnu učinkovitost zato što nova znanja i tehnološki napredak čine vrlo brzo znanje stečeno tijekom dodiplomskog usavršavanja zastarjelim (30). Postoji potreba za redovitim edukacijskim programima namijenjenima ažuriranju razine znanja stručnjaka $(29,30)$. No 50,7 \% sudionika izjavilo je da se dulje od dvije godine nisu upisali ni na jedan tečaj cjeloživotne izobrazbe. S druge strane, većina njih $(95,8 \%)$ pokazala je zanimanje za takve tečajeve u budućnosti, kao što je već uočeno (2). 


\section{Conclusion}

In this study, dentists from Primary Health Care Units in Brazil did not express a level of confidence required for the diagnosis of oral cancer. In addition, a questionnaire with open-ended questions could reveal even more worrying results. This calls for a change in educational and training programs on oral cancer during undergraduate dentistry courses. This will result in an increased number of trained professionals, capable of correctly diagnosing this disease. Moreover, public health care policies need to be revised to reduce morbidity and mortality due to this disease.

\section{Funding sources}

The research did not receive any funding.

\section{Acknowledgement}

This study was presented at the 42 Brazilian Congress of Oral Medicine and Oral Pathology, Manaus, Amazonas, Brazil, July 04-08, 2016.

\section{Conflict of interest statement}

The authors declare no conflict of interest.

\section{Zaključak}

U ovom istraživanju doktori dentalne medicine iz jedinica primarne zdravstvene zaštite u Brazilu nisu pokazali razinu znanja potrebnu za dijagnosticiranje oralnoga karcinoma. Uz to, upitnik s otvorenim pitanjima mogao bi otkriti još zabrinjavajućih rezultata. To zahtijeva promjenu u studijskim i nastavnim programima o oralnom raku tijekom dodiplomskog studija dentalne medicine. To će rezultirati povećanim brojem profesionalaca sposobnih za ispravno dijagnosticiranje te bolesti. Štoviše, javne zdravstvene smjernice treba revidirati kako bi se smanjili morbiditet i smrtnost zbog te bolesti.

\section{Izvori financiranja}

Ovo istraživanje nije dobilo nikakvu financijsku potporu.

\section{Zahvale}

Ovo istraživanje predstavljeno je na 42 . brazilskom kongresu orane medicine i oralne patologije (Brazilian Congress of Oral Medicine and Oral Pathology) u Manausu, u pokrajini Amazoniji od 4. do 8. srpnja 2016. godine.

\section{Izjava sukoba interesa}

Autori izjavljuju da nisu bili u sukobu interesa.

\begin{abstract}
Sažetak
Cilj: Željeli su se procijeniti znanje i stajališta o oralnome raku brazilskih doktora dentalne medicine u jedinicama primarne zdravstvene zaštite. Materijali i metode: Provedeno je prospektivno, presječno, epidemiološko istraživanje. Sa 71 doktorom dentalne medicine iz primarne zdravstvene zaštite kontaktiralo se na njihovu radnom mjestu i svi su se složili sa sudjelovanjem u istraživanju. Podatci su prikupljeni na temelju upitnika s 31 pitanjem s višestrukim izborom o glavnim kliničkim značajkama i rizičnim čimbenicima za karcinom usne šupljine. Upitnik je bio podijeljen u dva dijela - na pitanja koja se odnose na opće podatke i samopoimanje sudionika o osobnom znanju o oralnom karcinomu te na objektivna pitanja povezana s općim informacijama o oralnom karcinomu (klinička obilježja, karakteristike, svojstva i rizični čimbenici). Podatci su upisani u tablice i analizirani deskriptivnom statistikom. Rezultati: Sudionici su bile uglavnom žene $(81,5 \%)$ mlađe od 40 godina $(57,7 \%)$ koje su završile školovanje prije 10 do 20 godina (47,9\%). Većina (66,2\%) smatra da je razina njihova znanja o oralnom karcinomu zadovoljavajuća. No samo $26,8 \%$ istaknulo je da može obaviti dijagnostičke postupke u slučaju raka usne šupljine. Većina $(95,8 \%)$ je bila zainteresirana za sudjelovanje na tečajevima osposobljavanja za postavljanje oralne dijagnoze, a 56,3\% izjavilo je da nisu bili ni na kakvoj edukaciji ili nisu dobili smjernice o tome kako obaviti pregled za otkrivanje raka usne šupljine tijekom dodiplomskog školovanja. Zaključak: Ovi nalazi u skladu su s dosadašnjim izvješćima i upućuju na to da su potrebne nove javnozdravstvene smjernice kako bi se omogućila rana dijagnoza raka usne šupljine i obavila revizija kurikula o oralnoj medicini u školama dentalne medicine.
\end{abstract}

Zaprimljen: 21. kolovoza 2018. Prihvaćen: 12. veljače 2019.

Adresa za dopisivanje

Augusto César Leal da Silva Leonel Universidade Federal de Pernambuco Departamento de Clínica e Odontologia Preventiva. 4th Travessa Professor Artur de Sá, s/n. Cidade Universitária.CEP: $50740-$ 521.

Recife/PE, Brazil.

tel: $+55-87-99955-5788$.

faks: +55-81-2126-8817

augustocleal@hotmail.com

Ključne riječi

oralne novotvorine; zdravstvene spoznaje, stavovi i praksa; stomatolozi; primarna zdravstvena zaštita

\section{References}

1. Frola MI, Barrios R. Knowledge and attitudes about oral cancer among dental students after Bologna Plan implementation. J Cancer Educ. 2017 Sep;32(3):634-639.

2. Saleh A, Kong YH, Vengu N. Dentists' perception of the role they play in early detection of oral cancer. Asian Pac J Cancer Prev. 2014;15(1):229-37.

3. Applebaum E, Ruhlen TN, Kronenberg FR. Oral cancer knowledge, attitudes and practices: a survey of dentists and primary care physicians in Massachusetts. J Am Dent Assoc. 2009 Apr;140(4):461-7.

4. MeSH Browser [database on the Internet]. Brasil. Ministério da Saúde. Instituto Nacional do Câncer, Estimativa 2016. Brasília: INCA; 2018; [cited 2018 march 19]. Avaliable from: http://www.inca.gov.br/estimativa/2018.

5. Awojobi O, Scott SE, Newton T. Patients' perceptions of oral cancer screening in dental practice: a cross-sectional study. BMC Oral Health. 2012 Dec 18;12:55.

6. M S, Shetty P, Decruz AM. The Self-Reported Knowledge, Attitude and the practices regarding the early detection of oral cancer and precancerous lesions among the practising dentists of Dakshina Kannada-a pilot study. J Clin Diagn Res. 2013 Jul;7(7):1491-4.

7. Agrawal M, Pandey S, Jain S, Maitin S. Oral cancer awareness of the general public in Gorakhpur city, India. Asian Pac J Cancer Prev. 2012;13(10):5195-9.

8. Kujan O, Duxbury AJ, Glenny AM, Thakker NS, Sloan P. Opinions and attitudes of the UK's GDPs and specialists in oral surgery, oral medicine and surgical dentistry on oral cancer screening. Oral Dis. 2006 Mar;12(2):194-9.

9. Rocha-Buelvas A, Hidalgo-Patino C, Collela G, Angelillo I. Oral cancer and dentists: knowledge, attitudes and practices in a South Colombian context. Acta Odontol Latinoam. 2012;25(2):155-62.

10. Razavi SM, Tahani B, Nouri S. Oral Cancer Knowledge and prac tice among dental patients and their attitude towards tobacco cessation in Iran. Asian Pac J Cancer Prev. 2015;16:5439-5444.

11. Mehdizadeh M, Seyed Majidi M, Sadeghi S, Hamzeh M. Evaluation of knowledge, attitude and practice of general dentists regarding oral cancer in Sari, Iran. Iran J Cancer Prev. 2014 Spring;7(2):101-4. 
12. Horowitz AM, Drury TF, Goodman HS, Yellowitz JA. Oral pharyngeal cancer prevention and early detection. Dentists' opinions and practices. J Am Dent Assoc. 2000 Apr;131(4):453-62.

13. Mortazavi H, Baharvand M, Mehdipour M. Oral potentially malignant disorders: an overview of more than 20 entities. J Dent Res Dent Clin Dent Prospects. 2014 Winter;8(1):6-14.

14. Radoi L, Menvielle G, Cyr D, Lapôtre-Ledoux B, Stücker I, Luce D. Population attributable risks of oral cavity cancer to behavioral and medical risk factors in France: results of a large populationbased case-control study, the ICARE study. BMC Cancer. 2015 Oct 31;15:827.

15. Andrade JO, Santos CA, Oliveira MC. Associated factors with oral cancer: a study of case control in a population of the Brazil's Northeast. Rev Bras Epidemiol. 2015 Oct-Dec;18(4):894-905.

16. Vijay Kumar KV, Suresan V. Knowledge, attitude and screening practices of general dentists concerning oral cancer in Bangalore city. Indian J Cancer. 2012 Jan-Mar;49(1):33-8.

17. Marchioni DM, Fisberg RM, Francisco de Gois Filho J, Kowalski LP, Brasilino de Carvalho M, Abrahão M. Dietary patterns and risk of oral cancer: a case-control study in Sao Paulo, Brazil. Rev Saude Publica. 2007 Feb;41(1):19-26.

18. Toporcov TN, Tavares GE, Rotundo LD, Vaccarezza GF, Biazevic MG, Brasileiro RS. Do tobacco and alcohol modify protective effects of diet on oral carcinogenesis? Nutr Cancer. 2012;64(8):1182-9.

19. Chang IS, Lo HI, Wong TY, Huang CC, Lee WT, Tsai ST, et al. Investigating the association between oral hygiene and head and neck cancer. Oral Oncol. 2013 Oct;49(10):1010-7.

20. Franco EL, Kowalski LP, Oliveira BV, Curado MP, Pereira RN, Silva ME, et al. Risk factors for oral cancer in Brazil: a case-control study. Int J Cancer. 1989 Jun 15;43(6):992-1000.

21. Lissowska J, Pilarska A, Pilarski P, Samolczyk-Wanyura D, Piekarczyk J, Bardin-Mikolłajczak A, et al. Smoking, alcohol, diet, dentition and sexual practices in the epidemiology of oral cancer in Poland. Eur J Cancer Prev. 2003 Feb;12(1):25-33.
22. Yokoyama A, Tsutsumi E, Imazeki H, Suwa Y, Nakamura C, Yo koyama T. Contribution of the alcohol dehydrogenase-1B genotype and oral microorganisms to high salivary acetaldehyde concentrations in Japanese alcoholic men. Int J Cancer. 2007 Sep 1;121(5):1047-54.

23. Homann N, JouYesies-Somer H, Jokelainen K, Heine R, Salaspuro M. High acetaldehyde levels in saliva after ethanol consumption: methodological aspects and pathogenetic implications. Carcinogenesis. 1997 Sep;18(9):1739-43.

24. Rezende CP, Ramos MB, Daguila CH, Dedivitis RA, Rapoport A Oral health changes in with oral and oropharyngeal cancer. Braz J Otorhinolaryngol. 2008 Jul-Aug;74(4):596-600.

25. Chung CH, Bagheri A, D’Souza G. Epidemiology of oral human papillomavirus infection. Oral Oncol. 2014 May;50(5):364-9.

26. Mehanna H, Beech T, Nicholson T, El-Hariry I, McConkey C, Paleri $\mathrm{V}$, et al. Prevalence of human papillomavirus in oropharyngeal and nonoropharyngeal head and neck cancer--systematic review and meta-analysis of trends by time and region. Head Neck. 2013 May;35(5):747-55.

27. Zafereo ME, Xu L, Dahlstrom KR, Viamonte CA1, El-Naggar AK2, Wei Q, et al. Squamous cell carcinoma of the oral cavity often overexpresses $\mathrm{p} 16$ but is rarely driven by human papillomavirus. Oral Oncol. 2016 May;56:47-53.

28. Guneri P, Epstein JB. Late stage diagnosis of oral cancer: components and possible solutions. Oral Oncol. 2014 Dec;50(12):1131 6.

29. Pentenero M, Chiecchio A, Gandolfo S. Impact of academic and continuing education on oral cancer knowledge, attitude and practice among dentists in north-western Italy. J Cancer Educ. 2014 Mar;29(1):151-7.

30. Tadbir AA, Ebrahimi H, Pourshahidi S, Zeraatkar M. Evaluation of levels of knowledge about etiology and symptoms of oral cancer in southern Iran. Asian Pac J Cancer Prev. 2013;14(4):2217-20. 